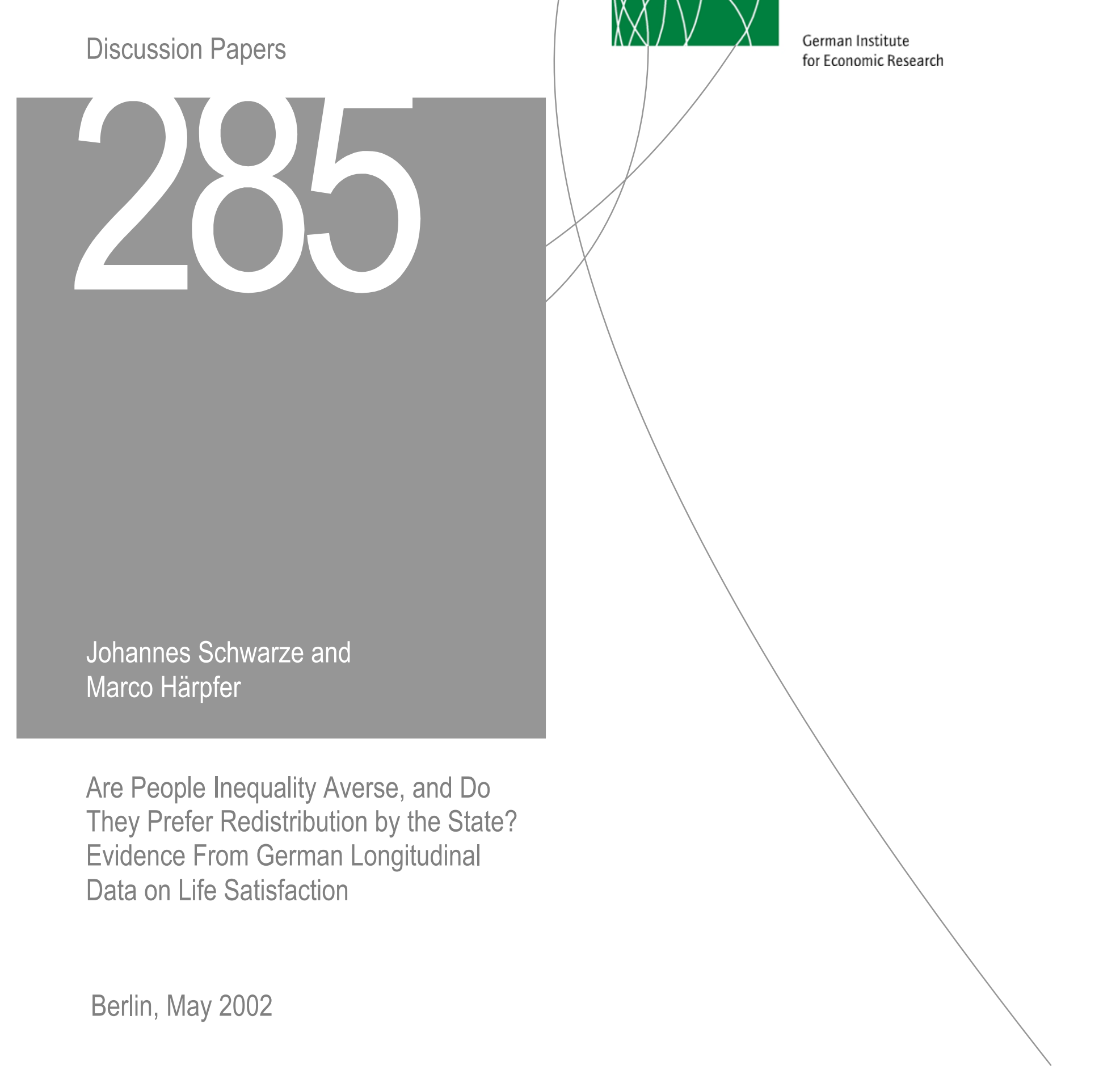


Opinions expressed in this paper are those of the author and do not necessarily reflect views of the Institute.

\section{DIW Berlin}

\section{German Institute}

for Economic Research

Königin-Luise-Str. 5

14195 Berlin,

Germany

Phone +49-30-897 89-0

Fax +49-30-897 89-200

www.diw.de

ISSN 1619-4535 


\title{
Are People Inequality Averse, and Do They Prefer Redistribution by the State? Evidence From German Longitudinal Data on Life Satisfaction
}

\author{
Johannes Schwarze ${ }^{\text {a),b) }}$ and Marco Härpfer ${ }^{\text {a) }}$ \\ December 2001 \\ a) University of Bamberg, Bamberg, Germany \\ b) DIW Berlin (German Institute for Economic Research), and IZA Bonn, Germany \\ e-mail: johannes.schwarze@sowi.uni-bamberg.de
}

\begin{abstract}
We link life-satisfaction data to inequality of the pre-government income distribution at the regional level, to estimate the degree of inequality aversion. In addition, we investigate whether a reduction in inequality by the state increases individual well-being. We find that Germans are inequality averse over the entire income distribution. However, inequality reduction by the state does not increase well-being. On the contrary, inequality reduction places something of an excess burden on middle-income earners. The paper uses data from the German Socio-economic Panel Study (GSOEP) from 1985 to 1998.
\end{abstract}

JEL Classification: C23, D31, D63, I31

Keywords: Inequality aversion, redistribution, life satisfaction, panel data.

We would like to thank Markus Pannenberg and Gert Wagner, Berlin, and seminar participants at the DIW Berlin for helpful comments. 


\section{Introduction}

Most industrialized countries redistribute income from the rich to the poor. Revenue from progressive income taxation and payroll taxation is distributed to individuals through monetary and non-monetary transfer payments. Redistribution policy reduces income inequality, from the perspective of the pre-government income distribution, and results in a more equal post-government income distribution. Table 1 shows the extent of income redistribution by the state for selected OECD countries. Inequality is measured by the Gini coefficient. It can be seen that Northern European countries reduce income inequality by about 50 percent, and Germany does so by 35 percent. Even in the United States, the reduction of pre-government inequality through redistribution is about 25 percent.

Table 1: Income redistribution by the state in selected OECD countries

\begin{tabular}{lccc}
\hline Country & $\begin{array}{c}\text { Gini Before Taxes } \\
\text { and Transfers (1) }\end{array}$ & $\begin{array}{c}\text { Gini After Taxes and } \\
\text { Transfers (2) }\end{array}$ & $\begin{array}{c}\text { \% Changes } \\
(2) /(1)-1\end{array}$ \\
\hline Germany, 1994 & 43.6 & 28.2 & -35.3 \\
Denmark, 1994 & 42.0 & 21.7 & -48.3 \\
Sweden, 1994 & 48.8 & 23.4 & -52.1 \\
Italy, 1993 & 51.0 & 34.5 & -32.4 \\
United States, 1995 & 45.5 & 34.4 & -24.5 \\
\hline
\end{tabular}

Note: All Gini coefficients are computed for household incomes using an equivalence scale elasticity of 0.5. Source: OECD, 1997.

While the circumstances under which individuals prefer redistribution by the state are discussed intensively by economic theorists, empirical work on this question is rare (for a literature review see Corneo and Grüner 2001). However, recent papers have used "stated preferences" from population surveys to analyze preferences for political redistribution.

Corneo (2001) and Corneo and Grüner (2000 and 2001) have used data from the International Social Survey Programme (ISSP) on 12 countries, including Eastern European countries, Germany, and the United States. They have analyzed responses to the question of whether it is the government's responsibility to reduce income differentials between people earning high incomes and those on low incomes. Three competing hypotheses that may lead individuals to support redistribution policies were tested. The "homo oeconomicus", or self-interest, effect measures whether individuals support redistribution because they expect to gain from these 
policy programs. The idea behind the "public values effect" is that there is a social welfare function that expresses individuals' preferences for a less unequal income distribution. Finally, the authors test a "social rivalry effect", which suggests that individual preferences for redistribution depend on the effect of redistribution on relative living standards. Corneo and Grüner (2001) find empirical support for each of the effects discussed. However, only the public values effect can be interpreted indirectly as evidence of inequality aversion. In this context, inequality aversion implies that individuals intrinsically prefer a less unequal income distribution independently of their own position in the income distribution.

Fong (2001) analyzes data from the 1998 Gallup Poll Social Audit Survey. The independent variable used in this study is a summative scale of five questions on whether or not governments should reduce inequality. While Fong (2001) finds little evidence for the hypothesis that redistribution is driven by self-interest, social preferences seem to be important.

The studies by Corneo and Grüner (2001) and Fong (2001) do not explicitly address the question of whether individuals are inequality averse. This is done by Alesina et al. (2001a), who analyze whether individuals are inequality averse by relating the inequality observed in society to individual differences in satisfaction with life. ${ }^{1}$ Life satisfaction may serve as an indicator of individual well-being. If people are inequality averse, income inequality should have a negative impact on life satisfaction. Like Corneo and Grüner (2001), Alesina et al. (2001a) also used cross-national survey data and found that preferences for a more equal income distribution are stronger in Western Europe than they are in the United States. The authors argue that preferences for a more equal income distribution may not only be due to "taste", but may also reflect something else in society, such as the level of social mobility (Alesina et al. 2001a, 19).

The study by Alesina et al. (2001a) provides no evidence that Europeans are inequality averse independently of their own income. While the authors found the poor to be deeply affected by inequality, they found nothing comparable among the rich. Alesina et al. (2001a) did not test whether inequality aversion generates support for redistribution policies.

\footnotetext{
${ }^{1}$ The paper by Alesina et al. (2001a) was published when the present paper was nearly finished.
} 
This paper links both questions. That is, we analyze whether people are inequality averse and whether inequality aversion is enough to lead people to support redistribution by the state. We use the German Socio-economic Panel Study (GSOEP), which provides information over a period of 14 years for West Germany on individual life satisfaction as well as information on several individual economic and socio-demographic determinants of life satisfaction. In addition, the use of panel data allows for control of unobserved individual heterogeneity and income mobility. For each year, pre-government and post-government income inequality is computed for 75 regional areas within West Germany. We interpret the difference between pre-government and post-government income inequality as the extent of political redistribution. Section 2 contains some theoretical considerations. Section 3 describes the data and the econometric model. The estimation results are presented in Section 4. Finally, Section 5 concludes the paper.

\section{Inequality Aversion and Preferences for Redistribution}

Economic theory offers a wide range of hypotheses to explain and legitimize redistribution by the state. For convenience, we summarize the main hypotheses with reference to three arguments as follows.

The first argument is one of economic efficiency. Individual preferences might be better satisfied by institutions such as the state if private transactions are affected by market failure.

The second argument is related to self-interest. Redistribution policy is driven by elections, group pressure, rent seeking, and so on. A popular model is that of the median voter. Another is the theory of Rawls (1971).

The basic hypothesis of the third argument is that people are (intrinsically) inequality averse, which means that inequality aversion enters individual utility functions. A possible justification for this is that individuals are altruistic or prefer a more equal income distribution, which then becomes something of a "public good" (see Thurow 1971 for a discussion). While the underlying motivation is of no interest to economists, whether such preferences provide additional legitimization (beyond efficiency concerns) for political redistribution is of interest. 
Distinctions can be made between these three arguments on the basis of whether inequality aversion is required. In addition, a major difference between the third argument and the other two is that, according to the former, some voluntary redistribution of income might be observed. Some points require discussion.

The first argument does not need inequality aversion to legitimize redistribution policies. If people are risk averse and are willing to pay to reduce the risk associated with their ex ante income distribution, they might support redistribution under certain circumstances (see, for example, Barr 1998, Sinn 1995). If no private insurance market exists because of (for example) asymmetric information or interdependent risks, compulsory social security can increase the welfare of all individuals. If insurance is compulsory, it is possible to pool high and low risks and charge everyone the average premium. Thus, social security systems redistribute income from low-risk to high-risk people. Although the average premium is high for individuals with low risk relative to their fair premium (income redistribution), these individuals would agree to a compulsory social security system, because under such a system, they would better off than if they had no insurance. Awareness of this may lead individuals to register preferences for redistribution policies (that is, people favor social security systems) that are both independent of their economic situation (for example, measured by gross income) and do not require inequality aversion.

Given the second argument above, people might be expected to support government policies designed to achieve a higher degree of redistribution if they expect to gain from these programs. Thus, redistribution is driven by self interest, in which case, support for redistribution should depend on individual income and social status, but also on income mobility. Recent research focuses on this issue in the context of the median-voter model (see Alesina et al. 2001a, b, Benabou and Ok 2001). Alesina et al. (2001a, 3) state that "this preference is mitigated by the fact that the poor of today may become the rich of tomorrow and they may not want to be in the future the ones who will support redistributive schemes." Thus, the degree of social mobility — that is, the probability of becoming rich in the futureshould influence the degree of support for redistributive policies. However, as Alesina et al. (2001b) and Benabou and Ok (2001) have shown formally, the relationships between income mobility, risk aversion, and the demand for redistribution are much more complex. When income mobility tends to zero- that is, income uncertainty is low-the median voter demands a high degree of redistribution. Greater mobility reduces redistribution if expected income 
shocks move the median voter up the income distribution - that is, income shocks have a positive mean. If income shocks have a negative mean, the demand for redistribution increases. When income shocks have a zero mean and people are risk averse, greater income mobility increases the demand for redistribution. Alesina et al. (2001b) interpret this result as a variant of the "maximin principle" of Rawls (1971).

In contrast to their findings for Europe, Alesina et al. (2001a) did not find any inequality aversion in the United States (US). One of their conclusions is that social mobility is higher in the US than in Europe. However, Burkhauser and Poupore (1997) and Maasoumi and Trede (2001) find evidence that income mobility in Germany is even higher than that in the US.

Summing up, the models discussed in the context of the second argument need not assume inequality aversion in the sense of altruism. Moreover, in the context of these models, inequality aversion might be better interpreted as risk aversion. This means that aversion to (ex post) income inequality is nothing other than an echo of individual risk aversion to the ex ante expected individual income distribution. Inequality aversion should be difficult to disentangle from risk aversion in empirical studies.

The basic idea behind the third argument above is that people are inequality averse independently of their economic status. Supposing that people are inequality averse in this sense, one could ask whether everyone would support redistribution by the state. Theoretically, altruistic preferences could be fully satisfied by private voluntary donations. However, as Hochman and Rodgers (1969) have shown, the "market for charity" can be subject to failure in large societies, especially if it is the overall distribution of income, rather than the incomes of specific poor individuals, that affects the utility of the rich. In this case, no voluntary changes in the income distribution would be observed. This might constitute a quasi-efficiency argument for compulsory redistribution by the government. The government tries to capture individual preferences for redistribution by a tax-financed transfer policy.

The following empirical question remains. How does the government's tax and transfer policy match individual preferences for redistribution? It might be difficult for the government to capture preferences for a less unequal income distribution if individual preferences are extremely heterogeneous. If preferences over income distributions are homogeneous, perhaps because of a national consensus, a tax and transfer policy may fit individual preferences 
better. In either case, if government policy matches individual preferences for a less unequal income distribution and preferences are reasonably homogeneous, most individuals should support redistribution by the government, because this would increase their welfare independently of their economic position. On the other hand, if no support is forthcoming, it might be fallacious to conclude that people are not inequality averse.

\section{Data and Econometric Model}

Our empirical approach is based on the idea of linking the perceptions of regional income inequality and the reduction of inequality by the government to individual data on life satisfaction. We measure inequality on a regional level. It can be assumed that individuals are affected more by inequality within their own region than by nationwide inequality. Regional inequality is observed by people as least as well as is nationwide inequality. In other words, if people are inequality averse in the sense discussed above, a regional measure of inequality should be at least as good as a national one. In addition, this approach has the advantage of increasing the number of observations on inequality in a national survey. If life satisfaction measures something akin to individual welfare, income inequality should have a negative effect on life satisfaction if people are inequality averse. A reduction in inequality through redistribution should have a positive effect on life satisfaction if people support redistributive policy.

As in some other surveys, a question on life satisfaction is asked in the GSOEP.

Table 2: Question on Life Satisfaction in the GSOEP.

Question: How satisfied are you with your life, all things considered?

Please answer according to the following scale: "0" means completely dissatisfied, "10" means completely satisfied.

Source: http://www.diw.de/deutsch/sop/service/fragen/index.html

For a long time, economists were very skeptical about satisfaction data because this type of data measures stated rather than revealed preferences. However, satisfaction data (and happiness data) have been used more frequently by economists in recent years. Satisfaction data has been used to analyze, among others, labor market issues (for example, Clark and Oswald 1994, Winkelmann and Winkelmann 1998), public choice-related issues (for 
example, Frey and Stutzer 2000), income, income uncertainty, and well-being (for example, Schwarze 1994, Schwarze 2000). (See Frey and Stutzer 2000 for an overview.) A recent approach by Van Praag et al. (2000) links satisfaction with different aspects of life to a structural model of life satisfaction. The paper by Alesina et al. (2001a) that links crossnational inequality to life satisfaction has already been mentioned. An early paper on this topic is by Morawetz et al. (1977), who compared the distributions of life satisfaction of communities with differing degrees of equality.

Analysis of life satisfaction by economists, and earlier and more recent work by psychologists (for an overview, see Diener et al. 1999, Frey and Stutzer 2000, Frey and Stutzer 2001, Van Praag et al. 2000) have shown that life satisfaction is a valid measure of individual well-being. Frey and Stutzer $(2000,159)$ conclude: "Happiness is a 'subjectivist' measure of individual welfare, and is much broader than the way individual utility is normally defined.... While happiness is not derived from actual behavior, it is systematically and closely connected with generally accepted manifestations of well-being." One could argue that life satisfaction not only measures individual utility, but also captures some aspects of a social utility function. Therefore, satisfaction data should show whether there are preferences for a less unequal income distribution.

The data used here are derived from the GSOEP, which is a representative longitudinal microdata base that includes a wide range of socio-economic information on randomly selected households in Germany. The first set of data was collected from approximately 6,000 families in the western states in 1984. After German re-unification in 1990, the GSOEP was extended by about 2,200 families from the eastern states. ${ }^{2}$ For estimation, we used an unbalanced panel for the years from 1985 to 1998 . We concentrate on the West German population of working age (between 20 and 60 years of age). Respondents who answered in at least two years are included.

Our econometric model is:

$$
S_{i r t}=X_{i r t}^{\prime} \beta_{1}+Y_{i r t}^{\prime} \beta_{2}+\operatorname{IPRE}_{r t} \beta_{3}+\operatorname{STATE}_{r t} \beta_{4}+\mu_{r}+v_{t}+\alpha_{i}+\varepsilon_{i r t}
$$

Life satisfaction, $S$, of person $i$ in region $r$ at time $t$ can be explained by a vector of individual socio-demographic characteristics, $X$, and by information on individual income and the

\footnotetext{
${ }^{2}$ The GSOEP data used in this study are available as a 'scientific use' file (see Wagner, Burkhauser, and Behringer 1993). For further information, please contact the German Institute for Economic Research (DIW), Berlin: http://www.diw.de/soep/.
} 
relative income position, represented by the vector $Y$. The coefficient vectors to be estimated are denoted by $\beta ; \mu_{r}$ is a fixed effect for the region in which the individual lives, $v_{t}$ is a fixed time effect, and $\varepsilon_{i r t}$ is an error term.

As responses to the life satisfaction question are from an ordinal scale, an appropriate estimator for our models is the ordered probit. However, the satisfaction scale may be used differently by different respondents (which is analogous to the ordinal-cardinal debate in utility theory). This may lead to correlations between unobserved characteristics and some included explanatory variables (for example, household income) and hence to inconsistent estimates of the parameters. However, the availability of panel data enables the model to be estimated as a fixed-effects or random-effects model, and thereby deals with some of these problems. In particular, if $\alpha_{i}$ is modeled as a fixed effect, it is possible to control for interindividual differences in the scaling and anchoring of responses, intrinsic differences in scaling, and unobserved variables. As long as this heterogeneity is constant over time, the estimators are unbiased. Unfortunately, there is no readily formulation of a fixed-effects ordered probit estimator available (see, e.g., Greene 2000). An alternative is to estimate a random-effects ordered probit model. However, the assumption that unobserved heterogeneity is independent of the explanatory variables seems untenable. Thus, we decided to estimate the following models. First, we estimate a pooled ordered probit, in which we cluster the variance-covariance matrix by individuals to relax the assumption of independence. Second, we estimate an ordinary least squares pooled regression, in which the variance-covariance matrix is also clustered by individuals. The signs and significance of the estimated parameters are substantively the same in both models. ${ }^{3}$ Third, we estimate a fixed-effects model to control for unobserved heterogeneity.

It could be argued that the repeated measurement of life satisfaction in panel data has an effect on respondents' answers. We control for this possibility by including a variable measuring the number of times a respondent has answered the question on life satisfaction.

The following socio-demographic characteristics, discussed in the literature as potential determinants of life satisfaction, are included: age, age squared, gender, nationality, years of education, marital status, whether widowed, whether divorced, household size, number of

\footnotetext{
${ }^{3}$ Hamermesh (2001) and DiTella et al. (2001) also used ordinary least-squares (OLS) to analyze satisfaction scales. They concluded that there are no substantial differences between OLS and ordered probit estimates.
} 
children, place of abode, whether employed full time, whether employed part time, and whether unemployed. Another important variable might be the health status of the individual. Unfortunately, there is no health measure in the GSOEP over the whole period.

The individual's income position enters the regression in the form of the log of equivalent household disposable income. We also include the relative income position of the individual in the form of the income quintile to which the person belongs. A dummy variable indicates whether the major source of household disposable income is a public transfer program. This might affect life satisfaction through stigmatization. In addition, we use the log of pregovernment household income as a predictor of life satisfaction. Including income as well as the individual's income position in a panel data model may well control for the income mobility effects discussed in Section 2. Panel data estimation methods make use of the withinindividual variation of the covariates and thus of changing income positions within the period under study.

Two variables included in Model (1) are central to our research and should be discussed in more detail. $I P R E_{\mathrm{rt}}$ is the inequality of the pre-government income distribution in region $r$ at time $t$. We compute inequality by using the regional income distribution for each respondent from the GSOEP. The regions are the 75 Raumordnungsregionen (ROR) of West Germany. The RORs are specific regional areas based on the administrative structure below the state level of West Germany (see Bundesamt für Bauwesen und Raumordnung 1999). ${ }^{4}$ Thus, we have $r$ multiplied by $t$ (that is, 75 multiplied by 14) observations on inequality.

First, we compute Gini coefficients for the pre-government income distribution for each of the 75 regions for each of the 15 waves.

$$
I P R E_{r t}=G\left(Y^{P R E}\right)_{r t}=\left[\frac{1}{2 n_{r}{ }^{2} \mu_{r}}\right] \sum_{i=1}^{n_{r}} \sum_{j=1}^{n_{r}}\left|y_{i r t}^{P R E}-y_{j r t}^{P R E}\right|
$$

Annual pre-government income $Y^{\mathrm{PRE}}$ is defined as the sum of gross earnings, capital income, and private transfer income across all household members.

The variable STATE measures the effect of government tax and transfer policy on the pregovernment income inequality of the regions as follows:

\footnotetext{
${ }^{4}$ The regional data can be obtained from the GSOEP group at the DIW Berlin (http://www.diw.de/soep/). See also Pannenberg and Schwarze (2000).
} 


$$
\text { STATE }_{r t}=\left|\frac{G\left(Y^{P O S T}\right)_{r t}}{G\left(Y^{P R E}\right)_{r t}}-1\right|,
$$

where post-government income $Y^{\mathrm{POST}}$ is defined as pre-government income minus income tax and payroll tax payments plus public transfer payments. Because both $Y^{\mathrm{PRE}}$ and $Y^{\mathrm{POST}}$ are calculated in the GSOEP at the household level, we use an equivalence scale so that households of different sizes are comparable. The scale chosen for our analysis approximates the widely accepted (revised) OECD scale. This scale assigns a weight of unity to the first adult, 0.5 to all other adults, and 0.3 to all children. ${ }^{5}$ Descriptive statistics for IPRE and STATE are reported in the appendix.

Model (1) enables a test of whether German people are inequality averse in general. Therefore, if inequality aversion is independent of an individual's own income, IPRE should have a negative impact on life satisfaction. If people support the reduction of inequality by the state, the variable STATE should have a positive sign. However, if inequality aversion and support for redistribution by the government is not independent of income, Model (1) is insufficient. This is especially so if the second argument (discussed previously) holds. Thus, we estimate a model that includes interaction effects between the individual's income position and regional inequality in place of overall inequality as follows:

$$
\begin{gathered}
S_{i r t}=X_{i r t}^{\prime} \beta_{1}+Y_{i r t}^{\prime} \beta_{2}+\operatorname{IPRE}_{r t} Q_{i r t}^{k} \beta_{3}+\operatorname{STATE}_{r t} Q_{i r t}^{k} \beta_{4}+\mu_{r}+v_{t}+\alpha_{i}+\varepsilon_{i r t} \\
k=1, \ldots, 5
\end{gathered}
$$

$Q^{\mathrm{k}}$ denotes the pre-government income quintile to which individual $i$ belongs. The quintiles are computed in accordance with the overall pre-government income distribution. It can be argued, however, that using regional inequality on the one hand and overall income quintiles on the other could be misleading. In this case, it would be better to calculate the income quintiles in accordance with the regional pre-government income distribution. However, some regions do not have enough observations for the computation of robust quintiles. Hence, for an alternative test of the argument, we compute relative income positions based on the regional mean pre-government income. We computed five income position classes, to each of which about 20 percent of the population belongs. People whose pre-government income is less than or equal to 60 percent of the regional mean pre-government income belong to the first class. Individuals whose income is between 60 percent and 95 percent of the mean income belong to the second class, and so on. The highest (fifth) class includes individuals whose pre-government income is more than 165 percent of the regional mean income. 
As pre-government inequality and inequality reduction by the state are measured on a regional level, both independent variables are more highly aggregated than is the dependent variable (life satisfaction). This may bias the estimated standard errors of the independent variables (see Moulton 1990). However, the panel data estimation methods used in this paper control for fixed regional effects and thus alleviate the problem.

\section{Estimation Results}

The empirical results are shown in the following tables. Only the estimated coefficients for inequality and inequality reduction are presented. The Appendix contains a table (Table A1) that includes all the estimated parameters. ${ }^{6}$ Most of the estimated parameters accord with those in the empirical literature on life satisfaction. Comparing the results with, for example, those found by Alesina et al. (2001a) on the basis of a completely different data set for European countries, one is struck by the similarities, not only of the sign and significance of the coefficients, but also in their magnitude. However, there are also differences. Whereas Alesina et al. (2001a) found that divorced people have a lower level of life satisfaction, we found a positive effect of divorce on life satisfaction when applying panel estimation methods. Divorce is a dynamic event, the effect of which on life satisfaction can only be ascertained by using information from a panel study.

As expected, life satisfaction increases with both the pre-government and net incomes of a household. The income position, measured by income quintiles, with the exception of the lowest income quintile, has no additional effect on life satisfaction. Compared with other individuals, those at the bottom of the income distribution are less satisfied with their life.

We now turn to the impact of inequality and inequality reduction by the state on life satisfaction and well-being. For clarity, Table 3 summarizes the potential effects of income inequality and inequality reduction through government policy on the basis of the three arguments discussed in Section 2. It should be pointed out, however, that it would be difficult to disentangle the empirical results on the basis of the different arguments. For example, if we do not find a negative impact of income inequality (IPRE) on life satisfaction on the one hand,

\footnotetext{
${ }^{5}$ The results discussed below are not sensitive to the equivalence scale chosen.
} 
but do find a positive effect of redistribution (STATE) on the other, it would not be possible to determine unequivocally whether redistribution is driven by efficiency or group interests.

Table 3: Possible effects of inequality and redistribution policy on well-being and life satisfaction

\begin{tabular}{lccc}
\hline Argument & Variable & Expected sign & Comment \\
\hline $\begin{array}{l}\text { Argument 1 } \\
\text { (Efficiency) }\end{array}$ & IPRE & 0 & No inequality aversion required \\
& STATE & + & Independent of income \\
\hline $\begin{array}{l}\text { Argument 2 } \\
\text { (Group interests, } \\
\text { median voter) }\end{array}$ & IPRE & 0 & No inequality aversion required \\
& STATE & + & For low incomes \\
& & - & For high incomes \\
\hline $\begin{array}{l}\text { Argument 3 } \\
\text { Inequality aversion) }\end{array}$ & IPRE & - & Independent of income \\
& STATE & $-/+$ & Depends on whether preferences are \\
& & & covered by government policy
\end{tabular}

Notes: IPRE is pre-government income inequality; STATE is the absolute percentage reduction in inequality by the government.

The parameter estimates reported in Table 4 indicate that pre-government income inequality has a significantly negative effect on life satisfaction. There are no substantial differences between the different models. This result might be interpreted as an indicator of inequality aversion. However, the effect might also be interpreted as the influence of specific regional characteristics such as high unemployment or a "bad" socio-economic structure. Both of these might lead to higher pre-government income inequality. Unfortunately, data on regional unemployment rates and social assistance take-up rates are not yet available for the period under study. When those data become available in the future, it will be possible to combine them with the GSOEP. Note, however, that all the models estimated here control for fixed regional effects. Thus, if regional structures do not change significantly over the observation period, such effects should be fully controlled for. ${ }^{7}$

\footnotetext{
${ }^{6}$ The appendix also presents estimates from a random-effects ordered probit model. The model here is estimated using STATA 7.0 and the module 'REOPROB' written by Guillaume R. Frechette (see, http://www.econ.ohiostate.edu/frechette/html/econ.htm).

${ }^{7}$ In addition, as Alesina et al. (2001a) have shown in their study of 12 European nations, the negative effect of income inequality on life satisfaction does not disappear when national unemployment rates are included.
} 
Table 4: Life satisfaction, inequality aversion, and political redistribution—estimates from panel data (selected variables)

\begin{tabular}{cccc}
\hline Variable & Ordered Probit & $\begin{array}{c}\text { Pooled } \\
\text { Regression }\end{array}$ & Fixed effects \\
\hline Pre-Government Inequality & $-0.3340^{* * *}$ & $-0.4710^{* * * *}$ & $-0.5009^{* * * *}$ \\
(IPRE) & $(0.1067)$ & $(0.1828)$ & $(0.1272)$ \\
Percent Redistribution (STATE) & -0.0323 & -0.1039 & $-0.1844^{*}$ \\
& $(0.0815)$ & $(0.1368)$ & $(0.1024)$
\end{tabular}

Robust standard errors in parentheses. Variance-covariance matrix for ordered probit and pooled regression is clustered by individuals.

Other variables: Age, age squared, sex, nationality, years of education, married, widowed, divorced, size of household, children, real estate, full time employed, part time employed, unemployed, disposable income (log), disposable income position (quintiles), pre-government income (log), public transfers, income taxes (percent), payroll taxes (percent), fixed time effects (14), fixed regional effects (73).

Statistically significant at the $10 \%$ level, ${ }^{* *}$ at the $5 \%$ level, ${ }^{* * *}$ at the $1 \%$ level.

N of cases: $94528 / 11838$.

Source: GSOEP, 1985-1998.

Redistribution by the state also has a negative effect on life satisfaction. However, the effect is statistically significant at only the 10 percent level in the case of the fixed-effects regression.

Before these results are discussed in greater detail, further investigation is required. Is inequality aversion independent of the individual's income position? It would not be surprising if people in a low-income position are averse to society's income distribution. A finding that only low-income households are inequality averse would not provide strong evidence of overall inequality aversion. This would require that the life satisfaction of individuals in the middle and at the top of the income distribution also are negatively affected by income inequality.

Table 5 reports the coefficients of the interaction terms between regional income inequality and the individual's income quintile position. ${ }^{8}$ Note that the income quintiles to which individuals belong are already controlled for by the inclusion of dummy variables (see Appendix, Table A1). In the ordered-probit model and the pooled regression model, not all estimated coefficients of pre-government income inequality interacted with the individual's pre-government income quintile position are significantly negative. Income inequality reduces life satisfaction of individuals belonging to the lower and to the highest income quintiles but not for the middle income classes. Looking at the fixed-effects regression, however, all

\footnotetext{
${ }^{8}$ An alternative procedure would be to include the main effects (IPRE, STATE) and four interaction effects. (The results are not shown here.) In this case, only the main effects are significant; the interaction effects are not.
} 
estimated coefficients are significantly negative. Thus, regional income inequality evidently reduces life satisfaction independently of the individual's own income position. The life satisfaction of people in the highest income position is negatively affected by income inequality, as is the life satisfaction of people who are in the middle or at the bottom of the income distribution. This result contrasts with that of Alesina et al. (2001a), who find that while the poor in European countries are affected by income inequality, the rich are not.

Although our results indicate a widespread inequality aversion in Germany, determining the possible causes would require further investigation. What are the reasons for such a widespread inequality aversion? Is a preference for more equality just a matter of "taste" or is there a broad consensus in society in favor of altruism? It is also possible that aversion to society's ex post income inequality reflects nothing more than individual risk aversion to the ex ante expected income distribution.

If pre-government income inequality reduces life satisfaction and thus welfare, can redistribution by the state increase life satisfaction? Table 5 shows a positive effect of redistribution on life satisfaction only for individuals belonging to the second income quintile. However, this effect is not statistically significant in the fixed-effects regression. Moreover, some estimated coefficients are significantly negative. The extent of redistribution by the state affects life satisfaction negatively for those people who are at the bottom of the income distribution. This might be explained by the possibility that redistribution is insufficient for those people. However, this effect is not found in the fixed-effects model.

A significantly negative effect on life satisfaction of the magnitude of redistribution is also found for individuals in the middle of the pre-government income distribution (third and fourth quintiles). The "middle class" in German society represents those most affected by income tax and payroll tax and thus those who finance most of the social burden. No significantly negative effect of income redistribution on life satisfaction was found for individuals at the top of the income distribution. 
Table 5: Life satisfaction, inequality aversion, and political redistribution by income quintiles—estimates from panel data (selected variables)

\begin{tabular}{|c|c|c|c|}
\hline Variable & Ordered Probit & $\begin{array}{c}\text { Pooled } \\
\text { Regression }\end{array}$ & Fixed effects \\
\hline \multicolumn{4}{|c|}{ Pre-Government Inequality by Quintiles: } \\
\hline \multirow[t]{2}{*}{ IPRE $^{*} \operatorname{PreQ}_{1}$} & $-0.3200^{* *}$ & $-0.5234^{*}$ & $-0.6431^{* * *}$ \\
\hline & $(0.1548)$ & $(0.2728)$ & $(0.1858)$ \\
\hline \multirow[t]{2}{*}{$\mathrm{IPRE}^{*} \mathrm{PreQ}_{2}$} & $-0.6178^{* * *}$ & $-0.9638^{* * *}$ & $-0.8412^{* * * *}$ \\
\hline & $(0.1425)$ & $(0.2446)$ & $(0.1690)$ \\
\hline \multirow[t]{2}{*}{$\mathrm{IPRE}^{*} \mathrm{PreQ}_{3}$} & -0.1121 & -0.1229 & $-0.3347^{* *}$ \\
\hline & $(0.1336)$ & $(0.2230)$ & $(0.1620)$ \\
\hline \multirow[t]{2}{*}{ IPRE $^{*}$ PreQ $_{4}$} & -0.1862 & -0.1801 & $-0.2801^{*}$ \\
\hline & $(0.1352)$ & $(0.2247)$ & $(0.1665)$ \\
\hline \multirow[t]{2}{*}{ IPRE $^{*}$ PreQ $_{5}$} & $-0.5071^{* * *}$ & $-0.6987^{* * *}$ & $-0.4707^{* * *}$ \\
\hline & $(0.1433)$ & $(0.2372)$ & $(0.1833)$ \\
\hline \multicolumn{4}{|c|}{ Percent Redistribution by Quintiles: } \\
\hline \multirow[t]{2}{*}{ STATE $^{*} \operatorname{PreQ}_{1}$} & $-0.2692^{*}$ & -0.4512 & -0.2826 \\
\hline & $(0.1587)$ & $(0.2826)$ & $(0.1870)$ \\
\hline \multirow[t]{2}{*}{ STATE $^{*}$ PreQ $_{2}$} & $0.2791^{* *}$ & $0.4416^{*}$ & 0.1177 \\
\hline & $(0.1355)$ & $(0.2297)$ & $(0.1639)$ \\
\hline \multirow[t]{2}{*}{ STATE $^{*} \operatorname{PreQ}_{3}$} & $-0.2469^{* *}$ & $-0.4299^{* *}$ & $-0.3262^{* *}$ \\
\hline & $(0.1239)$ & $(0.2016)$ & $(0.1548)$ \\
\hline \multirow[t]{2}{*}{ STATE $^{*} \mathrm{PreQ}_{4}$} & -0.1203 & -0.2922 & $-0.3097^{*}$ \\
\hline & $(0.1269)$ & $(0.2070)$ & $(0.1617)$ \\
\hline \multirow[t]{2}{*}{ STATE $^{*}{ }{ }^{2} Q_{5}$} & 0.2156 & 0.2453 & -0.1119 \\
\hline & $(0.1401)$ & $(0.2244)$ & $(0.1860)$ \\
\hline
\end{tabular}

Robust standard errors in parentheses. Variance-covariance matrix for ordered probit and pooled regression is clustered by individuals.

Other variables: Age, age squared, sex, nationality, years of education, married, widowed, divorced, size of household, children, real estate, full time employed, part time employed, unemployed, disposable income (log), disposable income position (quintiles), pre-government income (log), public transfers, income taxes (percent), payroll taxes (percent), fixed time effects (14), fixed regional effects (73).

Statistically significant at the $10 \%$ level, ${ }^{* *}$ at the $5 \%$ level, ${ }^{* * *}$ at the $1 \%$ level.

N of cases: $94528 / 11838$.

Source: GSOEP, 1985-1998.

In summary, while German people are negatively affected by income inequality, they do not prefer the current extent and/or structure of income redistribution by the government. Moreover, it seems that the middle-income class bears something of an "excess burden" of the government's redistribution policies. How might these results be interpreted? First, the government's redistribution policies evidently do not match individual preferences. In 
addition, as discussed in Section 2, one explanation might be the existence of some income mobility (where income shocks have a positive mean). Thus, income shocks move the median voter up the income distribution.

While we measured income inequality and its reduction by the state at the regional level, we calculated the individual's income position on the basis of quintiles of the overall German income distribution. However, it might be argued that what matters is not the income position in the overall income distribution, but the income position in the regional income distribution. As already mentioned, we cannot use individual income quintiles at the region level because some regions have too few observations. However, we can calculate the individual's income position on the basis of the mean regional income. The results are reported in Table 6. A comparison with Table 5 reveals no significant differences. Again, income inequality affects individual life satisfaction independently of the individual's regional income position. The coefficient is quite large for individuals in the lowest income position (pre-government income of less than or equal to 60 percent of the regional mean pre-government income) and for those in the highest income position (more than 160 percent). Again, we found a negative effect of redistribution on life satisfaction for people in middle income positions. 
Table 6: Life satisfaction, inequality aversion, and political redistribution by regional income position—estimates from panel data (selected variables)

\begin{tabular}{|c|c|c|c|}
\hline Variable & Ordered Probit & $\begin{array}{c}\text { Pooled } \\
\text { Regression }\end{array}$ & Fixed effects \\
\hline \multicolumn{4}{|c|}{$\begin{array}{l}\text { Pre-Government inequality by regional } \\
\text { income position: }\end{array}$} \\
\hline \multirow[t]{2}{*}{ IPRE ${ }^{*}$ Po1 } & $-0.5332^{* * *}$ & $-0.8672^{* * *}$ & $-0.8710^{* * * *}$ \\
\hline & $(0.1414)$ & $(0.2479)$ & $(0.1761)$ \\
\hline \multirow[t]{2}{*}{ IPRE ${ }^{*} \mathrm{Po} 2$} & -0.1976 & -0.2393 & $-0.6260^{* * *}$ \\
\hline & $(0.1327)$ & $(0.2266)$ & $(0.1766)$ \\
\hline \multirow[t]{2}{*}{ IPRE ${ }^{*}$ Po3 } & 0.0816 & 0.2289 & $-0.5902^{* * *}$ \\
\hline & $(0.1400)$ & $(0.2366)$ & $(0.1865)$ \\
\hline \multirow[t]{2}{*}{ IPRE ${ }^{*} \mathrm{Po} 4$} & $-0.3159^{* *}$ & $-0.4192^{*}$ & $-0.6282^{* * *}$ \\
\hline & $(0.1417)$ & $(0.2378)$ & $(0.1905)$ \\
\hline \multirow[t]{2}{*}{ IPRE ${ }^{*}$ Po5 } & $-0.6121^{* * *}$ & $-0.8900^{* * *}$ & $-0.5556^{* * *}$ \\
\hline & $(0.1491)$ & $(0.2465)$ & $(0.1998)$ \\
\hline \multirow{2}{*}{\multicolumn{4}{|c|}{$\begin{array}{l}\text { Percent redistribution by regional income } \\
\text { position: }\end{array}$}} \\
\hline & & & \\
\hline \multirow[t]{2}{*}{ STATE*Po1 } & -0.0618 & -0.0942 & -0.0187 \\
\hline & $(0.1549)$ & $(0.2765)$ & $(0.1834)$ \\
\hline \multirow[t]{2}{*}{ STATE*Po2 } & $-0.2522^{* *}$ & $-0.4671^{* *}$ & -0.2386 \\
\hline & $(0.1267)$ & $(0.2135)$ & $(0.1636)$ \\
\hline \multirow[t]{2}{*}{ STATE Po3 } & $-0.4975^{* * *}$ & $-0.8746^{* * *}$ & -0.2049 \\
\hline & $(0.1319)$ & $(0.2197)$ & $(0.1679)$ \\
\hline \multirow[t]{2}{*}{ STATE*Po4 } & -0.0201 & -0.0943 & $-0.2784^{*}$ \\
\hline & $(0.1299)$ & $(0.2136)$ & $(0.1650)$ \\
\hline \multirow[t]{2}{*}{ STATE Po5 } & $0.3549^{* *}$ & $0.4814^{* *}$ & -0.2565 \\
\hline & $(0.1393)$ & $(0.2248)$ & $(0.1717)$ \\
\hline
\end{tabular}

Robust standard errors in parentheses. Variance-covariance matrix for ordered probit and pooled regression is clustered by individuals.

Other variables: Age, age squared, sex, nationality, years of education, married, widowed, divorced, size of household, children, real estate, full time employed, part time employed, unemployed, disposable income (log), disposable income position (quintiles), pre-government income (log), public transfers, income taxes (percent), payroll taxes (percent), fixed time effects (14), fixed regional effects (73).

Statistically significant at the $10 \%$ level, ${ }^{* * *}$ at the $5 \%$ level, ${ }^{* * *}$ at the $1 \%$ level.

$N$ of cases: $94528 / 11838$.

Source: GSOEP, 1985-1998. 


\section{Conclusions}

Using panel data covering a 14-year period between 1985 and 1998, we regressed life satisfaction, rated on a scale ranging from 0 to 10 , on regional pre-government income inequality and on the percentage reduction in inequality achieved through tax and transfer policy.

The results show that German people are strongly affected by pre-government income inequality. Increasing income inequality reduces life satisfaction and thus individual wellbeing. We found this effect to be independent of the individual's income position, which suggests an overall preference for equality among German people. A possible interpretation of this result is one of inequality aversion due to altruism, or alternatively, one of a more equal income distribution being a kind of public good.

Redistribution through government tax and transfer policy evidently cannot reduce welfare loss that is due to income inequality. We found no positive effect on life satisfaction of the percentage reduction in inequality. Moreover, individuals in the middle of the income distribution are affected negatively by redistribution. The estimated reduction in life satisfaction that is due to redistribution might be interpreted as a form of "excess burden".

Further research could address the following questions. What is behind measured income inequality? Is it the extent of income inequality that lowers individual welfare or does something else that is correlated with income inequality reduce life satisfaction? Although we controlled for fixed regional effects, regional characteristics such as unemployment rates, social assistance take-up rates, and crime levels could usefully be included in the models estimated in this paper.

\section{References}

Alesina, Alberto, Rafael Di Tella, and Robert MacCulloch, Inequality and Happiness: Are Europeans and Americans Different? (Cambridge: National Bureau of Economic Research, NBER Working Paper 8198, 2001a).

Alesina, Alberto, Edward Glaeser, and Bruce Sacerdote, Why Doesn't the US have a European-Style Welfare System? (Cambridge: National Bureau of Economic 
Research, NBER Working Paper 8524, 2001b).

Barr, Nicolas, The Economics of the Welfare State, 3rd edition (Oxford: Oxford University Press, 1998).

Benabou, Roland, and Efe A. Ok, "Social Mobility and the Demand for Redistribution: The POUM Hypothesis", Quarterly Journal of Economics 116 (2001), 447-487.

Buhmann, Brigitte, Lee Rainwater, Günther Schmaus, and Timothy J. Smeeding, "Equivalence Scales, Well-Being, Inequality, and Poverty: Sensitivity Estimates Across Ten Countries using the Luxembourg Income Study (LIS) Database", Review of Income and Wealth 34 (1988), 115-142.

Bundesamt für Bauwesen und Raumordnung, Aktuelle Daten zur Entwicklung der Städte, Kreise und Gemeinden, Ausgabe 1999 (Bonn: Bundesamt für Bauwesen und Raumordnung, Berichte Band 3, Selbstverlag, 1999).

Burkhauser, Richard V., and John G. Poupore, "A Cross-national Comparison of Permanent Inequality in the United States and Germany", Review of Economics and Statistics 79 (1997), 10-17.

Clark, Andrew E., and Andrew J. Oswald, "Unhappiness and Unemployment", Economic Journal 104: 648-659.

Corneo, Ciacomo, Inequality and the State: Comparing U.S. and German Preferences (Munich: Center for Economic Studies and Ifo Institute for Economic Research, Working Paper 398, 2001).

_ , and Hans Peter Grüner, "Social Limits to Redistribution”, American Economic Review 90 (2000), 1491-1507.

— of Public Economics (forthcoming, 2001).

Diener, Ed., Eunkook Suh, Richard Lucas, and Heidi Smith, "Subjective Well-Being: Three Decades of Progress", Psychological Bulletin 125 (1999), 276-303.

Di Tella, Rafael, Robert J. MacCulloch, and Andrei J. Oswald, "Preferences over Inflation and Unemployment: Evidence from Surveys of Happiness", American Economic Review 91 (2001), 335-341.

Fong, Christina, "Social Preferences, Self-interest, and the Demand for Redistribution", Journal of Public Economics 82 (2001), 225-246.

Frey, Bruno S., and Alois Stutzer, "Maximizing Happiness?", German Economic Review 1 (2000), 145-167.

Frey, Bruno S., and Alois Stutzer, What can Economists Learn from Happiness Research? 
(Munich: Center for Economic Studies and Ifo Institute for Economic Research, Working Paper 503, 2001).

Greene, William H., Econometric Analysis, 4th edition (London: Prentice-Hall International 2000).

Hamermesh, Daniel S., "The Changing Distribution of Job Satisfaction", Journal of Human Resources 36 (2001), 1-30.

Hochman, Harold M., and James D. Rodgers, "Pareto Optimal Redistribution", American Economic Review 59 (1969), 542-557.

Maasoumi, Esfandiar, and Mark Trede, "Comparing Income Mobility in Germany and the United States Using Generalized Entropy Mobility Measures," Review of Economics and Statistics 83 (2001), 551-559.

Morawetz, David, et al., "Income Distribution and Self-rated Happiness: Some Empirical Evidence", Economic Journal 87 (1977), 511-522.

Moulton, Brent, "An Illustration of a Pitfall in Estimating the Effects of Aggregate Variables on Micro Units", Review of Economics and Statistics 72 (1990), 334-338.

van Praag, Bernard M. S., Individual Welfare Functions and Consumer Behavior (Amsterdam: 1968).

- , P. Frijters, and A. Ferrer-i-Carbonel, Towards a Nested Structural Model of Wellbeing: Eliciting preferences through subjective questions (Amsterdam: University of Amsterdam and Tinbergen Institue, 2000).

Pannenberg, Markus, and Johannes Schwarze, "Wage Dynamics and Unemployment in Germany: Evidence from Regional Panel Data”, Labour (forthcoming, 2001).

Rawls, John A Theory of Justice (Cambridge: Harvard University Press 1971).

Schwarze, Johannes, Subjective Measures of Economic Well-Being and the Influence of Income Uncertainty (Berlin: German Institute for Economic Research, Discussion Paper 94, 1994).

Schwarze, Johannes, Using Panel Data on Income Satisfaction to Estimate the Equivalence Scale Elasticity (Bonn: Institute for the Study of Labor (IZA), Discussion Paper 224, 2000).

Sinn, Hans-Werner, “A Theory of the Welfare State”, Scandinavian Journal of Economics 97 (1995), 495-526.

Thurow, Lester C., "The Income Distribution as a Pure Public Good", Quarterly Journal of Economics 85 (1971), 327.

Wagner, Gert G., Richard V. Burkhauser, and Frederike Behringer, "The English Language 
Public Use File of the German Socio-Economic Panel", Journal of Human Resources 28 (1993), 429-433.

Winkelmann, Liliana, and Rainer Winkelmann, "Why are the Unemployed so Unhappy? Evidence from Panel Data", Economica 65 (1998), 1-15. 


\section{Appendix}

Table A1: Life satisfaction, inequality aversion and political redistribution - Estimates from panel data 1985 to 1998

\begin{tabular}{|c|c|c|c|c|}
\hline Variable & $\begin{array}{l}\text { Ordered } \\
\text { Probit }\end{array}$ & $\begin{array}{c}\text { Random- } \\
\text { effects } \\
\text { ordered } \\
\text { probit }\end{array}$ & $\begin{array}{c}\text { Pooled } \\
\text { Regression }\end{array}$ & $\begin{array}{l}\text { Fixed- } \\
\text { effects } \\
\text { regression }\end{array}$ \\
\hline Age & $\begin{array}{c}-0.0532^{* * *} \\
(0.0046)\end{array}$ & $\begin{array}{c}-0.0472^{* * *} \\
(0.0039)\end{array}$ & $\begin{array}{c}-0.0893^{* * * *} \\
(0.0078)\end{array}$ & $\begin{array}{c}-0.4978 \\
(0.4758)\end{array}$ \\
\hline Age squared & $\begin{array}{c}0.0006^{* * * *} \\
(0.0001)\end{array}$ & $\begin{array}{l}0.0004^{* * * *} \\
(0.0000)\end{array}$ & $\begin{array}{c}0.0009^{* * *} \\
(0.0001)\end{array}$ & $\begin{array}{l}0.0003^{* * *} \\
(0.0001)\end{array}$ \\
\hline Female & $\begin{array}{c}0.0569^{* * *} \\
(0.0158)\end{array}$ & $\begin{array}{c}0.0995^{* * *} \\
(0.0187)\end{array}$ & $\begin{array}{l}0.0926^{* * *} \\
(0.0269)\end{array}$ & - \\
\hline Foreign guest worker & $\begin{array}{c}0.0542^{* * *} \\
(0.0188)\end{array}$ & $\begin{array}{l}0.0403^{* * * *} \\
(0.0219)\end{array}$ & $\begin{array}{l}0.0744^{* * *} \\
(0.0318)\end{array}$ & - \\
\hline Years of education & $\begin{array}{l}0.0098^{\text {**** }} \\
(0.0033)\end{array}$ & $\begin{array}{l}0.0127^{* * *} \\
(0.0035)\end{array}$ & $\begin{array}{l}0.0205^{* * * *} \\
(0.005)^{* * * *}\end{array}$ & $\begin{array}{l}-0.0027 \\
(0.0097)\end{array}$ \\
\hline Married & $\begin{array}{c}0.1808^{* * * *} \\
(0.0192)\end{array}$ & $\begin{array}{l}0.2270^{* * * *} \\
(0.0165)\end{array}$ & $\begin{array}{l}0.3084^{* * * *} \\
(0.0326)\end{array}$ & $\begin{array}{l}0.2726^{* * * *} \\
(0.0250)\end{array}$ \\
\hline Divorced & $\begin{array}{c}-0.0239 \\
(0.0340)\end{array}$ & $\begin{array}{c}0.0917 \\
(0.0278)\end{array}$ & $\begin{array}{l}-0.0524 \\
(0.0609)\end{array}$ & $\begin{array}{l}0.2280^{* * * *} \\
(0.0414)\end{array}$ \\
\hline Widow/Widower & $\begin{array}{c}0.0284 \\
(0.0540)\end{array}$ & $\begin{array}{c}-0.0835 \\
(0.0472)\end{array}$ & $\begin{array}{c}0.0359 \\
(0.0938)\end{array}$ & $\begin{array}{c}-0.2363^{* * * *} \\
(0.0792)\end{array}$ \\
\hline Number of household members & $\begin{array}{c}-0.0629^{* * *} \\
(0.0063)\end{array}$ & $\begin{array}{c}-0.0724^{* * *} \\
(0.0052)\end{array}$ & $\begin{array}{c}-0.1045^{* * * *} \\
(0.0108)\end{array}$ & $\begin{array}{c}-0.0807^{* * * *} \\
(0.0079)\end{array}$ \\
\hline Number of Children & $\begin{array}{c}0.0723^{* * * *} \\
(0.0162)\end{array}$ & $\begin{array}{c}0.0445^{* * *} \\
(0.0131)\end{array}$ & $\begin{array}{c}0.1308^{* * * *} \\
(0.0273)\end{array}$ & $\begin{array}{c}0.0513^{* * * *} \\
(0.0189)\end{array}$ \\
\hline Own house & $\begin{array}{c}0.0911^{* * *} \\
(0.0154)\end{array}$ & $\begin{array}{c}0.0606^{* * * *} \\
(0.0136)\end{array}$ & $\begin{array}{c}0.1497^{* * * *} \\
(0.0257)\end{array}$ & $\begin{array}{c}0.0044 \\
(0.0216)\end{array}$ \\
\hline Full time employed & $\begin{array}{c}0.0633^{* * *} \\
(0.0160)\end{array}$ & $\begin{array}{c}0.0959^{* * * *} \\
(0.0130)\end{array}$ & $\begin{array}{c}0.1304^{* * * *} \\
(0.0271)\end{array}$ & $\begin{array}{l}0.1574^{* * * *} \\
(0.0194)\end{array}$ \\
\hline Part time employed & $\begin{array}{c}-0.0188 \\
(0.0215)\end{array}$ & $\begin{array}{c}-0.0264 \\
(0.0183)\end{array}$ & $\begin{array}{c}-0.0022 \\
(0.0357)\end{array}$ & $\begin{array}{l}-0.0059 \\
(0.0252)\end{array}$ \\
\hline Self employed & $\begin{array}{l}-0.0355 \\
(0.0266)\end{array}$ & $\begin{array}{l}-0.0103 \\
(0.0193)\end{array}$ & $\begin{array}{l}-0.0734^{*} \\
(0.0378)\end{array}$ & $\begin{array}{l}-0.0212 \\
(0.0284)\end{array}$ \\
\hline Unemployed & $\begin{array}{c}-0.3687^{\text {**** }} \\
(0.0229)\end{array}$ & $\begin{array}{c}-0.3856^{* * *} \\
(0.0188)\end{array}$ & $\begin{array}{c}-0.7054^{* * *} \\
(0.0429)\end{array}$ & $\begin{array}{c}-0.5269^{* * * *} \\
(0.0263)\end{array}$ \\
\hline Household income (log) & $\begin{array}{c}0.2334^{* * * *} \\
(0.0256)\end{array}$ & $\begin{array}{c}0.2452^{* * *} \\
(0.0225)\end{array}$ & $\begin{array}{c}0.4267^{* * * *} \\
(0.0457)\end{array}$ & $\begin{array}{c}0.3193^{* * * *} \\
(0.0311)\end{array}$ \\
\hline $\begin{array}{l}\text { Pre-government household income } \\
\text { (log) }\end{array}$ & $\begin{array}{l}0.0322^{* * *} \\
(0.0056)\end{array}$ & $\begin{array}{l}0.0318^{* *} \\
(0.0046)\end{array}$ & $\begin{array}{l}0.0652^{* * *} \\
(0.0105)\end{array}$ & $\begin{array}{l}0.3869^{* * *} \\
(0.0066)\end{array}$ \\
\hline Lowest income quintile & $\begin{array}{l}-0.0721^{* *} \\
(0.0365)\end{array}$ & $\begin{array}{l}-0.0705 \\
(0.0321)\end{array}$ & $\begin{array}{l}-0.1048^{*} \\
(0.0636)\end{array}$ & $\begin{array}{l}-0.0494 \\
(0.0440)\end{array}$ \\
\hline Second income quintile & $\begin{array}{l}-0.0233 \\
(0.0268)\end{array}$ & $\begin{array}{l}-0.0276 \\
(0.0233)\end{array}$ & $\begin{array}{l}-0.0115 \\
(0.0469)\end{array}$ & $\begin{array}{l}-0.0018 \\
(0.0322)\end{array}$ \\
\hline Third income quintile & $\begin{array}{l}-0.0115 \\
(0.0212)\end{array}$ & $\begin{array}{l}-0.0014 \\
(0.0185)\end{array}$ & $\begin{array}{l}-0.0016 \\
(0.0365)\end{array}$ & $\begin{array}{c}0.0203 \\
(0.0256)\end{array}$ \\
\hline Fourth income quintile & $\begin{array}{c}0.0041 \\
(0.0161)\end{array}$ & $\begin{array}{c}0.0193 \\
(0.0148)\end{array}$ & $\begin{array}{c}0.0216 \\
(0.0272)\end{array}$ & $\begin{array}{l}0.0424^{* * *} \\
(0.0203)\end{array}$ \\
\hline
\end{tabular}




\begin{tabular}{lcccc}
\hline Household receives social assistance & $-0.1181^{* * *}$ & $-0.0481^{* * * *}$ & $-0.1925^{* * *}$ & -0.0151 \\
& $(0.0352)$ & $(0.0308)$ & $(0.0668)$ & $(0.0424)$ \\
Pre-Government Inequality (IPRE) & $-0.3340^{* * *}$ & $-0.4506^{* * *}$ & $-0.4710^{* * *}$ & $-0.5015^{* * *}$ \\
& $(0.1067)$ & $(0.0940)$ & $(0.1828)$ & $(0.1273)$ \\
Percent Redistribution (STATE) & -0.0323 & -0.1036 & -0.1039 & $-0.1841^{*}$ \\
& $(0.0815)$ & $(0.0761)$ & $(0.1368)$ & $(0.1024)$ \\
Number of questionnaires filled in & $0.0038^{* * *}$ & $0.0073^{* * *}$ & $0.0090^{* * *}$ & - \\
& $(0.0019)$ & $(0.0022)$ & $(0.0031)$ & \\
\hline
\end{tabular}

Other variables: Fixed time effects (14), fixed regional effects (73).

*Statistically significant at the $10 \%$ level, ${ }^{* *}$ at the $5 \%$ level, ${ }^{* * *}$ at the $1 \%$ level.

$N$ of cases: $94528 / 11838$.

Source: GSOEP, 1985-1998.

Table A2: Description of regional areas (Raumordnungsregionen) for 1985 and 1998

\begin{tabular}{lcc}
\hline Numbers of individuals per & \multicolumn{2}{c}{ Numbers of regional areas } \\
\cline { 2 - 3 } regional area & 1985 & 1998 \\
$<=30$ & 22 & 15 \\
$>30 \&<=70$ & 26 & 32 \\
$>70 \&<=100$ & 13 & 10 \\
$>100$ & 14 & 18 \\
\hline
\end{tabular}

Source: GSOEP, 1985-1998. 
Figure A1: Pre-Government Income Inequality (Gini) West-German regional areas (Raumordnungsregionen) 1985

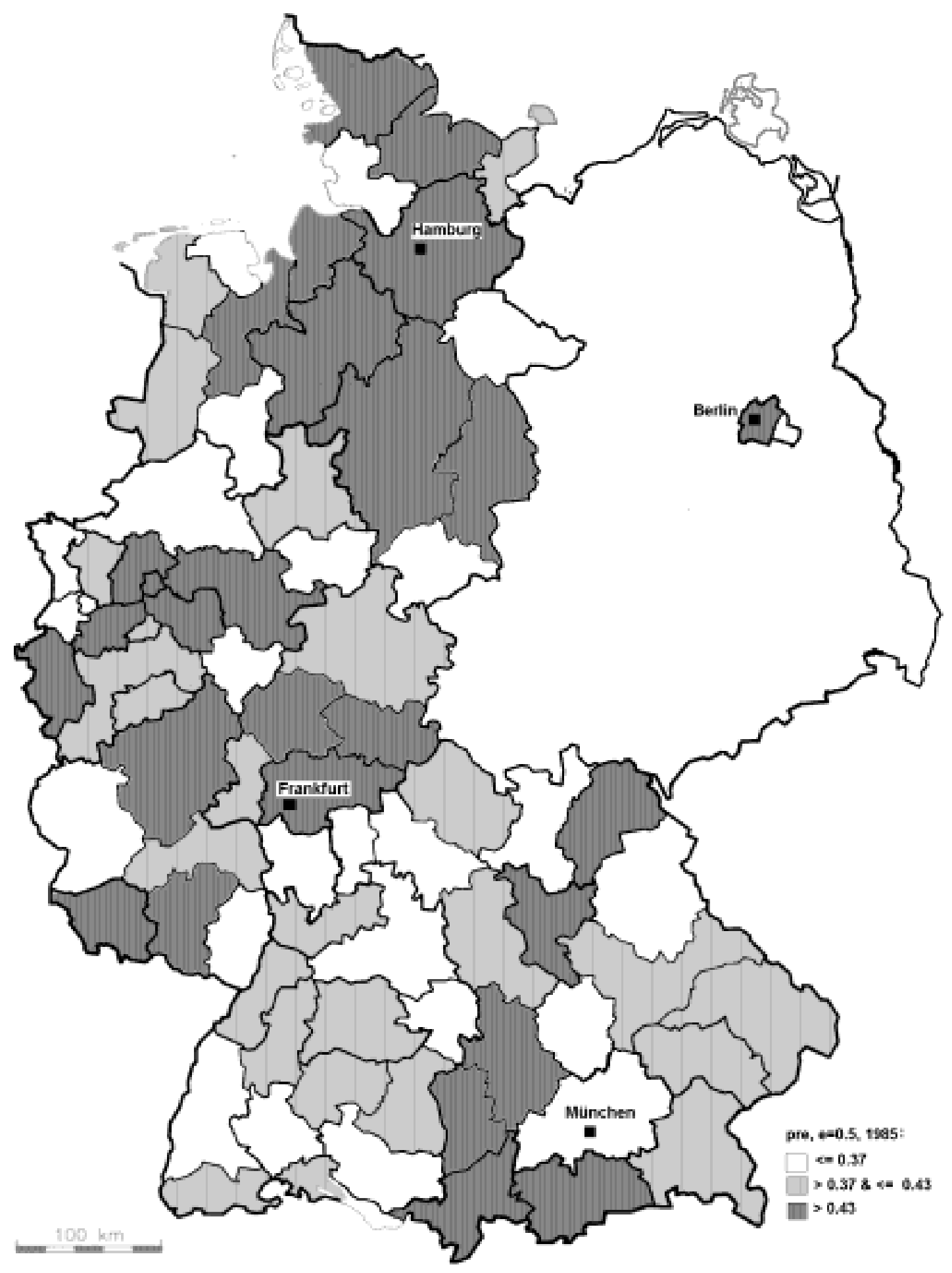

Source: GSOEP, 1985. 
Figure A2: Pre-Government Income Inequality (Gini) West-German regional areas (Raumordnungsregionen) 1998

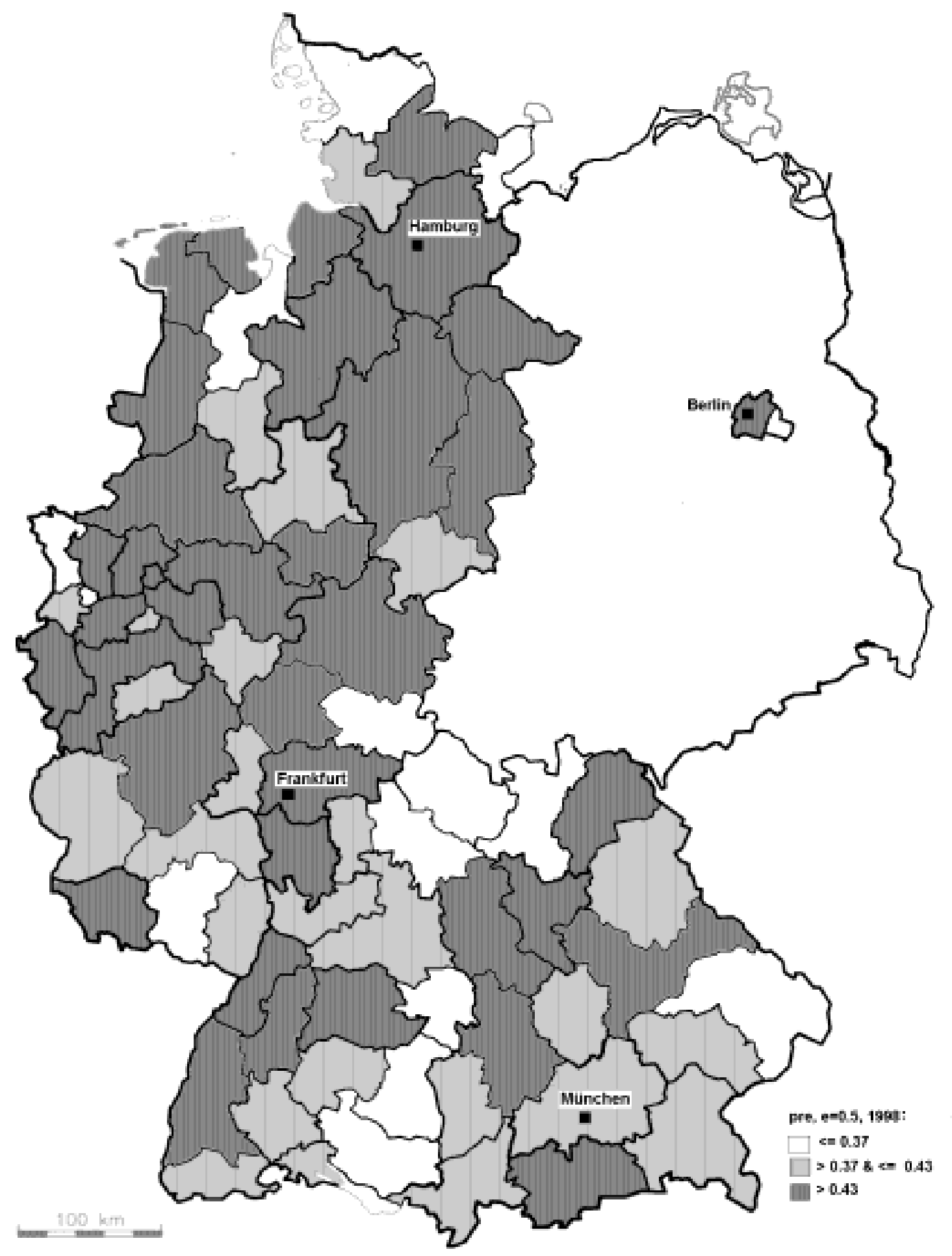

Source: GSOEP, 1998. 
Figure A3: Redistribution by the state in West-German regional areas

(Raumordnungsregionen) 1985

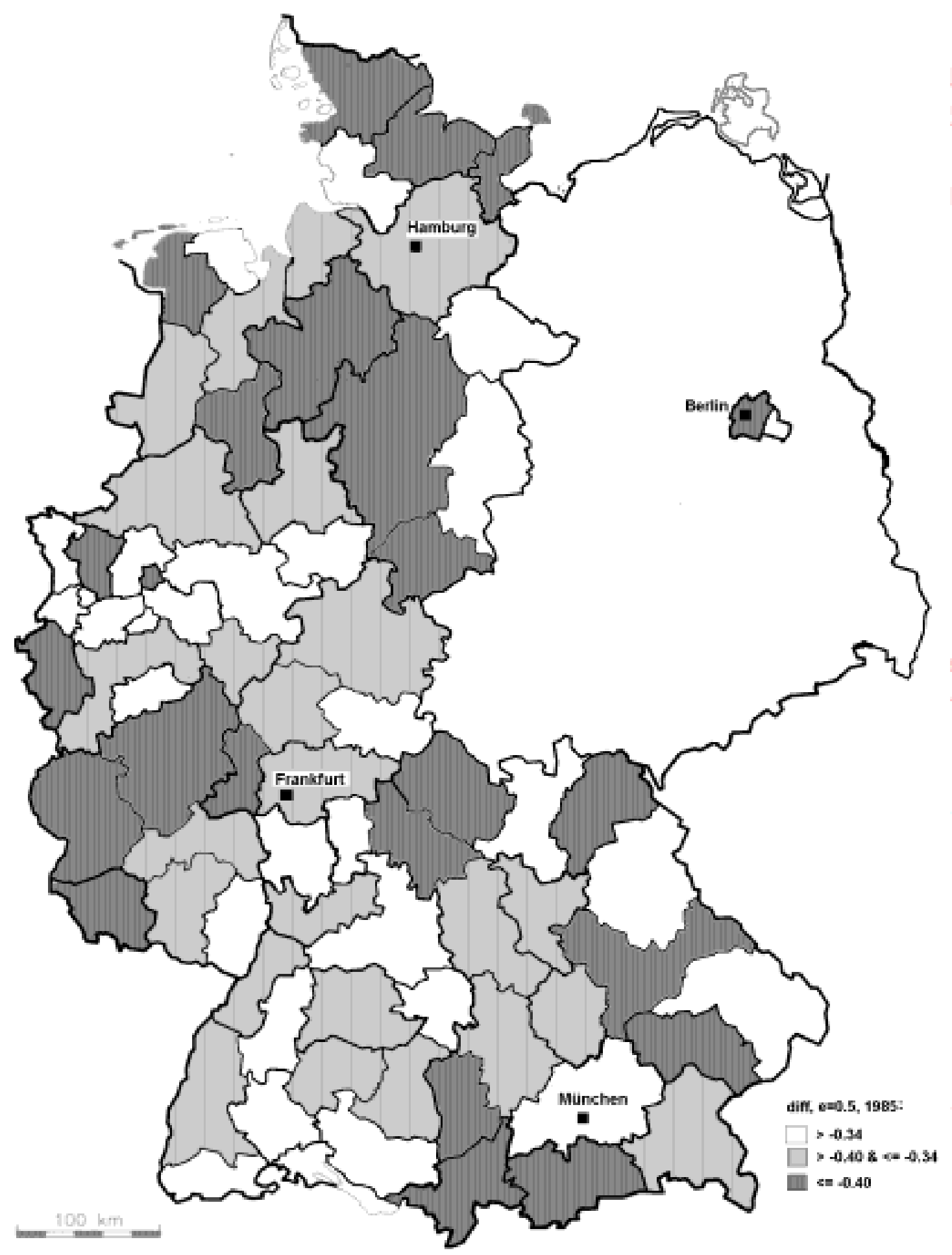

Notes: Redistribution is measured as Gini(Post-Government Income)/Gini(Pre-Government Income)-1. Source: GSOEP, 1985. 
Figure A4: Redistribution by the state in West-German regional areas

(Raumordnungsregionen) 1998

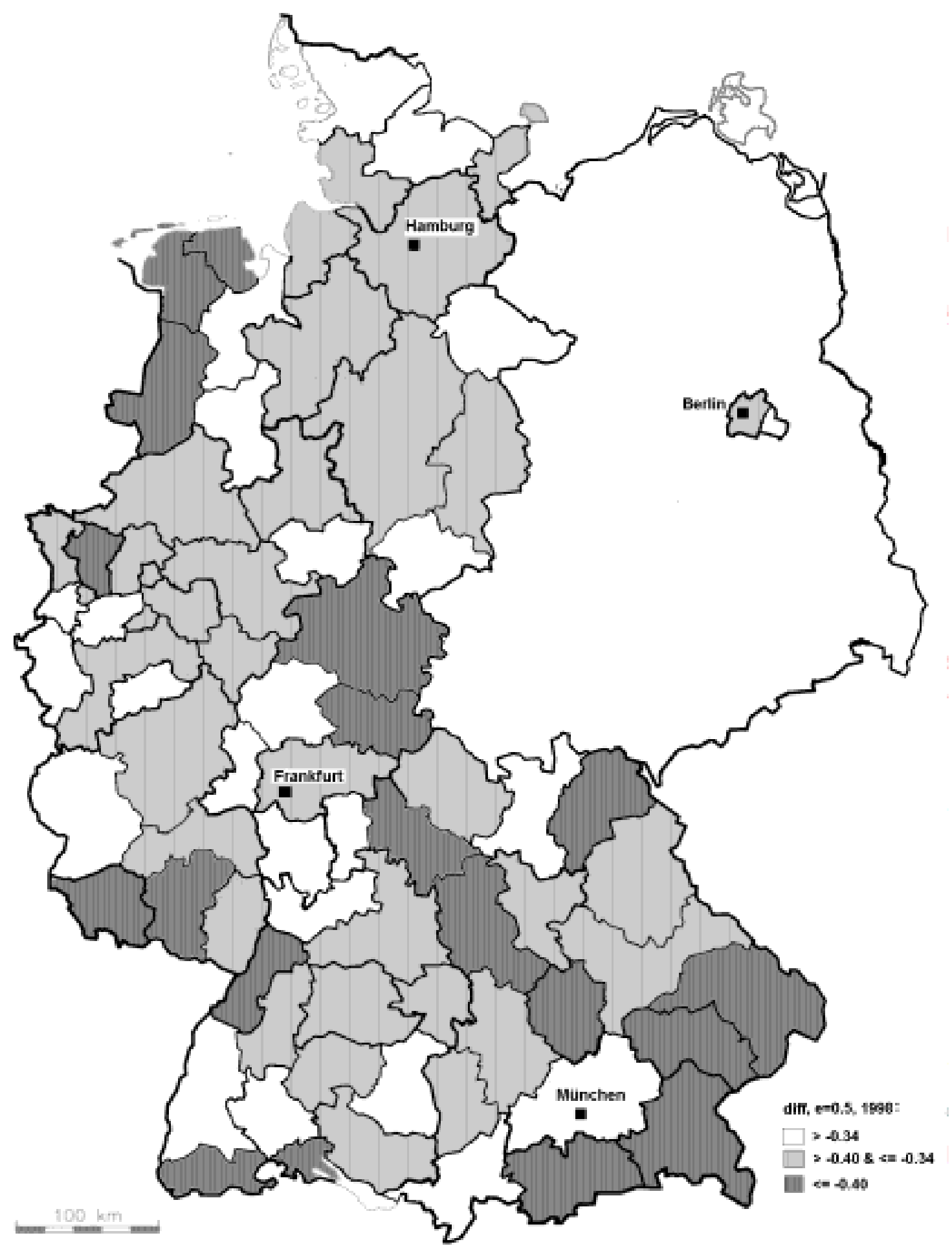

Notes: Redistribution is measured as Gini(Post-Government Income)/Gini(Pre-Government Income)-1. Source: GSOEP, 1998. 